\title{
4. Transformation of Albania in transition. POPULATION AND SOCIO-ECONOMIC ASPECTS
}

\subsection{INTRODUCTION}

Albania is situated in the southeastern part of the European continent. It is bordered by the Republic of Serbia and Montenegro to the north, north-west and north-east, in the south-east by the Republic of Macedonia, Greece to the south and by the Adriatic Sea to the west which separates it from Italy. Albania has an area of 28 thousand $\mathrm{km}^{2}$ and a population around 3,4 million inhabitants. It's an integral part of the Balkan Peninsula. From the physical-geographical point of view it is characterized by a hilly-mountainous area, where Mediterranean weather dominates. It has hydrographic resources of all types such as seas, rivers, lakes. All these factors combined together have contributed to the comprehensive development of the economy in this European country.

However we must estimate that as a result of historical political developments which have passed through in the history of Albania, the above elements haven't been properly targeted and haven't had the attention that should be shown to them as an important factor in the development of a country. Also an important role belongs to the construction of political relations that have existed in this country. The predominance of a totalitarian communist system for a period of nearly 45 years didn't bring the expected economic developments. By developing a socialist economy the Albanian economy didn't create the identity that it should had, but instead it turned into an annex of the former socialist economies which Albania cooperated with at that time.

Priority was given to agricultural and livestock production with a relative development to some industry branches. We should emphasize the important groundwater and natural resources and assets of the country, which have served 
continually as constant opportunities for development and are not historically exploited the values and opportunities that should be done. The many diverse tourist assets and resources were in minimum exploitation phase so the tourist influx hadn't a relative influence in the Albanian economy at that time. The economic development was centralized and planned with the impossibility of privatization process. Meanwhile in the country had emerged the first performances of social problems dealing with problems such as unemployment, in many cases the impossibility to ensure minimum income for living, the lack in supply of food products, elements of poverty, also lack in meeting the population demands for settlements.

The population was concentrated mainly in rural areas even though it's seen from year to year a certain minimum growth trend of the population concentrated in urban centers. The number of births continued to be high and was kept this way affecting the natural growth of the Albanian population.

This was precisely the economic, social and demographic situation of Albania in the early transition years, or as called in Albania, at the beginning of the democracy related to the early1990s.

\subsection{TRANSFORMATION OF THE ECONOMIC ASPECTS IN TRANSITION PERIOD}

The Albanian economy of the after 90s is distinguished by a very important element, which is related to the fact of changing its image and presentation, from a centrally planned economy to that of the market economy. Many researchers emphasize in their studies that the problem of which the Albanian economy faced in this period had to do not only with its content, which is linked to mode of production and management, but also with other aspects, mainly the structural character of its branches, the contribution that these branches of economy provide to country's general production.

Albania for a period of 45 years was a representation of a country predominating by the agricultural production and average levels of industrial contribution to the country's economy, even though in the context of national contribution to the country's general production; industry and agriculture were listed approximately equally in such figures respectively $41 \%$ and $37 \%$. It should be noted that during the transition period the contribution of agriculture continued to dominate, despite the fact that its level has undergone fluctuations by increasing and decreasing from year to year, appearing in 1990s with a specific weight of $37 \%$, while in 2005 with a weight of $54 \%$, but the industrial production suffered a considerable decrease in the early 90s, which in those first years from a specific weight of about $41 \%$ fell down gradually to $25 \%$ and now it comes out with a contribution of about $12 \%$ in the country's economy. 
After the 90s we see a significant difference in the structure of the economy branches, as it started to grow continually the specific influence of sectors such as construction, services and transportation. Today the weight of these sectors represents respectively $11 \%, 15 \%$, and $5 \%$, constantly showing their growing tendency in the context of GNP (general national production). The latter, as researchers and analysts assumed in their economic studies, are characterized by a distinctive attribute, which is related to their distribution of areas in the whole country, in contrast to the industry development that is concentrated only in certain areas.

A key change is related to innovations that the privatization process brought in Albania, also the first contributions that brought in many sectors the implementation of the principal of market economy. Thus, in the general industrial and agricultural production, the private sector soon will intensify its contribution figures being represented by about $70 \%$ of his presence in 2005 , whereas in the early 90s it was $0 \%$. Another indicator that must be stressed out in the transition period of the Albanian economy, is related to its privatization, the continually increase of mainly small enterprises, which include industrial and service production.

Furthermore, in 1993, which were the first years of transition, the number of small enterprises reached to 2493 and in 1999 to 23028 . Also a significant change is related to the fact that even the territorial distribution areas of the economy branches changed a lot. In particular it should be noted that a lot of important industrial and agricultural centers, that existed before 90s in different cities and districts of Albania, lost their economic importance, bringing a bigger concentration especially in areas around Tirana and Durres, transforming those two centers to important metropolis and main arteries of the country's economic development.

Another element which deserves to be taken into consideration and to be presented as a feature of the country's economic development during the transition is the dependency of many branches of the economy on imports. Import-export ratios are in favor of imports and official statistics show the fact that a negative balance that prevailed at the beginning of transition which varied about 72 million \$, today it appears in about 500 million \$. Export includes mainly agricultural and livestock products, some light industry and handicraft items, and a part of some mineral products. Import includes everything in terms of industrial and agricultural products of all types. An important feature of the Albanian economy in transition period is the role and contribution of the foreign capital invested in Albania. Particularly, foreign investments incoming in Albania, influenced not only by increasing the production and creating a "breathing" in the economy, but immediately affected in the creation of new workplaces where many Albanians were employed. The main orientation of 
foreign investors has been mainly in light-industry and processing, construction, transport and services sector. Official statistics, economic geographers and economist scholars inform that $35 \%$ of the total investment belongs to the service sector, $20 \%$ to the light-industry and processing, $15 \%$ to the construction sector, about $6 \%$ to transportation. Foreign investors in Albania are mainly Italian and Greek, and few others who occupy a small specific weight.

A characteristic of these foreign investments is their concentration mainly in Tirana, Durres, Vlore, Fier, Gjirokaster and Saranda, which apparently is related to the near distance of their borders with these cities, as well as the country's main ports such as Vlora and Saranda. A bigger investment in these cities is related to the stabilized social situation of these areas.

Unemployment is one of the most vulnerable and disturbing social problems that have accompanied especially the working population, in this transition period in Albania. Closure of many plants and factories caused for a large number of workers, who had worked for years in them, to be forced to stay unemployed and in this way creating favorable premises for the decline of living standard in Albania. It should be noted that in the first years precisely due to changing the economic system into the market economy, led unemployment in Albania to be a massive phenomenon. We must say that official statistics in Albania verified the fact that unemployment level varied in different cities of the country, while at national level has had a variable curb in 15 years in a row, reaching the highest level of about $30 \%$ of the active population. Later when these enterprises entered the privatization path some workers who had first worked there and others with professional level, joined the beginning of different production cycles in them.

\subsection{EVOLUTION OF THE ALBANIA POPULATION IN THE TRANSITION PERIOD. SOCIAL INSURANCE ASPECTS AND HIS ROLE IN POPULATION}

Like any other filed or aspect of the developments in Albania and its population, the transition was accompanied with some special features, entirely closely linked to demographic elements. It should be noted that in the general panorama of Albanian population in this period a lot of new elements are appeared, among which should be identified external or international migration, internal emigration is shown with new forms, reduced annual rates of population growth, even begins to be seen a new demographic element which relates to reduced population number, decreasing trends in population natural growth, decreasing in birth numbers, etc.

In general, international emigration destinations were bordered territories with Albania such as Italy and Greece; other destinations were Western European countries like Germany in particular, while other countries had a lower 
emigration by Albanians. Other performances of international emigration, which was evidenced in the second half of the 90s, are related mainly with American and Canadian lottery, through which we witness departing of many Albanian families, mostly intellectuals. Other important destinations were even those included in the periodic emigration type, mainly because of seasonal employment, in neighboring border countries such as Montenegro and Macedonia, this during the agricultural works, as well as that of summer and winter tourist flow.

Scholars and analysts of various population studies, characterize this phenomenon of Albanians mass emigration in the early 90s, as an opportunity given to them for a better economic life and political freedom, considering the isolation that characterized Albanian communism period, also the difficult economic situation, in the context of the full crisis that was going through Albanian economy during that period. Official statistics show that Albanian emigration included about 600000 people of different ages and categories, needs to be recorded the fact that emigration prevails to young people, which will soon affect the emergence of demographic consequences in the Albanian population, but also reduction of natural growth.

Albanian population resulted in 3,2 million inhabitants in the early $90^{\text {th }}$, while in 2001 resulted in 3,06 million inhabitants, confirming that one of the main causes of direct impact in the decrease of population number was Albanians' mass emigration. Of course this is also related to other factors, such as problems of birthing and mortality, population natural dislocation.

Internal migration was accompanied by new phenomena's which were not present in the population dislocations at first. While before it was dominant a controlled and planned population movement, after the 90s with the establishment of democracy it is noted an uncontrolled population movement. It's seen a considerable population dislocation from rural to urban areas. These movements were directed more towards large cities and in their suburbs are concentrated and also have created their own community many incomers from different country's territories. Such a situation is presented mainly in Tirana the capital, but also in other important cities such as Durres, Shkoder , Korce, Fier, Elbasan, etc.

Such migrate movement from small to large cities has been influenced by economic but also social factors. Economic factors are dominant because of the impossibility that the resources of those areas had to provide for their population, also closely linked to other aspect as the closure of many industrial and agricultural factories, initiation of the privatization process, etc, which left behind thousands unemployed people. Social factors have also an impact for other population categories, which migrate in other cities for a better life, better education, professional career, or influenced by public tranquility that in 
different times of the transition period was problematic in many cities of the country.

A very significant and indicating element for a country's population features is the natural population growth, which as mentioned above in the transition period had a considerable decrease. Analysts and researchers identify two determinant factors among others, which have influenced the decline of population natural growth rates, year by year in this period. The first factor relates to the fact of massive immigration which led to immediate decline of natural growth values. This factor is closely linked with another important demographic element, population age structure. The emigrated population apparently was carrying aging regenerative capacity of the population, mostly young age or reproductive age.

The second factor has to do with the significant decline of birth numbers. Until the 90s Albania is distinguished for the higher rate of number of births, but this changed immediately after the 90s. The first argument relates to the young age that left the country, the second argument deals not only with the beginning of public campaigns of family planning, but also new mentalities that joined Albanian families such as limiting the number of children, for a more comfortable life, career reasons etc. The birth falling number is closely associated with the uncertain economic situation that accompanied the transition period of Albanian society in general and families in particular.

Official statistics confirm the fact of this decline that has suffered in years the number of births in Albania, which resulted in 1989 in 82 thousand births, while ten years later resulted in 53 thousand births. In the population natural growth another demographic element has a considerable effect, which has to do with mortality. This indicator has always been decreasing. The decline of births has influenced in leading to lower population natural growth in the following years. When in 1990 the value has been about 19,6 inhabitants per 1000 inhabitants, in 2000 its value is reduced to 11,1 inhabitants per 1000 inhabitants.

A considerable decrease has had also the annual average index. For a period of almost ten years 1990-2001 the annual average pace has remained in negative values around $-0,3 \%$ per year, but in the 90 s the annual average pace of population growth resulted in positive values about $1,9 \%$.

This shows at the same time that during this period we are dealing with an ongoing decline in the number of population. 


\subsection{ALBANIAN POPULATION DURING THE YEARS ACCORDING TO INSTAT DATA}

As we see from the table 1 above, it presents Albanian population in different periods of time, the frequency of absolute growth in the number of population in Albania, is noticed only during the period 1989 to 2001, a period that responds to the transition period, where the population consistently addressed to its absolute reduction.

Table 1

Evolution of the Albania population in the transition period

\begin{tabular}{|l|c|c|c|}
\hline Years & Population & $\begin{array}{c}\text { Population density } \\
\text { per km }{ }^{2}\end{array}$ & Number of families \\
\hline 1930 & 833618 & 30,3 & 146249 \\
\hline 1950 & 1122044 & 42,0 & 211613 \\
\hline 1960 & 1626315 & 56,6 & 279805 \\
\hline 1969 & 2068155 & 71,9 & 346588 \\
\hline 1979 & 2590600 & 90,1 & 463333 \\
\hline 1989 & 3182417 & 110,7 & 675456 \\
\hline 2001 & 3069275 & 106,7 & 726895 \\
\hline
\end{tabular}

Source: author's own elaboration.

All these economic and demographic developments have been in mutual influence with a lot of social problems, among which unemployment is identified. This is one of the tangible problems, important and influential in population during the transition period, even in many demographic processes that had an immediate effect in the Albanian families. The emergence and growth of such an element, was especially influenced by the economic development in the early transition, where privatization application begun in the country's economy. This led a considerable number of workers and specialists to remain unemployed, being in a crossroad regarding their future of how to ensure their families livelihood.

High unemployment figures are present in large administrative territories, especially in important cities of the country. Such a thing is due to numerous arrivals in the context of internal migration in these territories. At the same time it should be noted that high unemployment is recorded in many northern and northeastern country's administrative territories, which from the point of view of general economy even though they have numerous natural resources they don't have industrial development, large or medium business, to get employed more 
and more people. Various official statistics show a high number of unemployment in Kukes about 33,8\% of working-capable population, in Has about 29,3\%, in Shkoder about 28\%, etc.

We must stress out that young people are facing unemployment more; this causes their migration into other cities of the country, where can be easier to find a job, better economic incomes, but also brings to their international emigration.

\subsection{CONCLUSIONS}

The Albanian economy after 90s is distinguished for a very important element, which relates to the fact of changing its image and presentation, from a centrally planned economy to that of the market economy.

Albania for a period of 45 years was a reflection of a country predominating by the agricultural production and average levels of industrial contribution to the country's economy, even though in the context of national contribution to the country's general production; industry and agriculture were listed approximately equally in such figures respectively $41 \%$ and $37 \%$.

It should be noted that during the transition period the contribution of agriculture continued to dominate, despite the fact that its level has undergone fluctuations by increasing and decreasing from year to year, appearing in 1990s with a specific weight of $37 \%$, while in 2005 with a weight of $54 \%$, but the industrial production suffered a considerable decrease in the early 90 s, which in those first years from a specific weight of about $41 \%$ fell down gradually to $25 \%$ and now it comes out with a contribution of about $12 \%$ in the country's economy.

A key change is related to innovations that the privatization process brought in Albania, also the first contributions that brought in many sectors the implementtation of the principal of market economy. Thus, in the general industrial and agricultural production, the private sector soon will intensify its contribution figures being represented by about $70 \%$ of his presence in 2005 , whereas in the early 90 s it was $0 \%$.

We see significant difference in the structure of the economy branches, as it started to grow continually the specific weight of sectors such as construction, services and transportation. Today the impact of these sectors represents respectively $11 \%, 15 \%$, and $5 \%$, constantly showing their growing tendency in the context of GNP (general national production).

An important feature of the Albanian economy in the transition period is the role and contribution of the invested foreign capital.

In this period a lot of new elements of the Albanian population are identified, among which should be mentioned external or international migration, internal emigration is exposed on new forms, reduced annual rates of population growth, 
even it is to be seen a new demographic element which is related to the reducing of population number, decreasing trends in population natural growth, decreasing in birth numbers, etc.

We must stress that young people are facing unemployment more; this causes their migration into other cities of the country, where can be easier to find a job, better economic incomes, but also brings to their international emigration.

\section{BIBLIOGRAPHY}

Axhemi S., 1995, A general overview of Albania in 1990-1995 period, Manuscript, report hold in the University of Barcelona.

Axhemi S., 2004, Traditional and actual opinions about regional geography, (co-author), "Scientific Bulletines at Shkodra,s University”, Social Sciences Series.

Axhemi S., 2005, Economic, demographic, social aspects of boundary territories at Shkodra’s region, “Geographic Studies”, № 15, Tirane.

Axhemi S., 2005, Environment and tourism. Problems and perspectives at Shkodra's region, Special book, published at University of Shkodra.

Axhemi S., 2007, Geography of population, Tirane.

Axhemi S., Todisco E., Sokoli N., 2003, Migration's problems in Albania. Current situations and tendencies in the future, "Geographical Studies”, № 16, Tirane.

INSTAT, 1990-2005, Bulletins of statistical index information.

Laçi S., Sheme S., 2005, Human geography of Albania, Tirane.

\section{STRESZCZENIE}

\section{ZMIANY GOSPODARCZE PODCZAS PRZEJŚCIA DEMOGRAFICZNEGO W ALBANII.} ASPEKTY LUDNOŚCIOWE I SPOŁECZNO-EKONOMICZNE

Praca omawia zmiany ludnościowe i społeczno-ekonomiczne w Albanii w okresie przejścia demograficznego rozpatrywane w powiązaniu z położeniem geograficznym, warunkami naturalnymi i politycznymi. Po ogólnej analizie przemian gospodarczych zachodzących podczas przejścia demograficznego, autor szczegółowo naświetlił nowe zmiany w rozwoju demograficznym, migracjach międzynarodowych i wewnętrznych oraz ruchu naturalnym.

Prof. dr Sokol Axhemi 